\title{
Pseudotumour cerebri in lupus
}

\author{
Rashmi Roongta $^{1} \cdot$ Arghya Chattopadhyay $^{1}$ (D) $\cdot$ Shashwat Bhattacharyya ${ }^{2} \cdot$ Alakendu Ghosh $^{1}$
}

Received: 20 October 2020 / Revised: 1 November 2020 / Accepted: 8 November 2020 / Published online: 10 November 2020

(C) International League of Associations for Rheumatology (ILAR) 2020

\section{Case presentation}

A 24-year-old woman presented with skin rash, headache, and transient blurring of vision of 3 weeks and facial puffiness of 1 week duration. On examination, she was afebrile; body mass index was $25 \mathrm{~kg} / \mathrm{m}^{2}$ with malar rash, pedal edema, and facial puffiness. Her visual acuity was normal, and fundoscopy showed the presence of bilateral papilledema (Fig. 1a). Magnetic resonance (MR) imaging of the brain and MR venogram were normal. Cerebrospinal fluid (CSF) opening pressure was $27 \mathrm{~cm}$ of water (normal: $<20 \mathrm{~cm}$ ) with normal cell count, protein, and sugar. Her reports showed anemia, total leucocyte counts of 7800 per cumm (normal: 450011,000 per cumm), erythrocyte sedimentation rate of $56 \mathrm{~mm} / \mathrm{h}$ (normal: $<20 \mathrm{~mm} / \mathrm{h}$ ), normal C-reactive protein, positive direct Coomb's test, positive antinuclear antibody, high dsDNA, low complements, and negative antiphospholipid antibody (APLA) workup. The renal evaluation showed a 24-h urinary protein of $4.8 \mathrm{~g} /$ day, and renal biopsy revealed class V Lupus nephritis. She was pulsed with $500 \mathrm{mg}$ of methylprednisolone for 3 days in view of established papilledema and elevated creatinine, followed by oral steroids and mycophenolate mofetil for nephritis. She noticed an improvement in headache and visual complaints within a few days. Repeat fundoscopy after 3 weeks showed near-complete resolution of papilledema (Fig. 1b). She was diagnosed as having lupus-related intracranial hypertension.

\section{Discussion}

Idiopathic intracranial hypertension (IIH) in lupus has a reported prevalence of $0.7 \%$. It is associated with nephritis, arthritis, rash, cytopenias, APLA syndrome, and active disease but not with obesity [1]. Presentation of lupus with IIH, like in this case, is rare [1]. Reduced CSF absorption due to disruption of the blood-brain barrier by immune-mediated injury of the arachnoid villi and/or vascular occlusion due to a hypercoagulable state are the proposed pathogeneses of this condition $[2,3]$. Other postulated mechanisms are vasculitis, aseptic meningitis, immune complex precipitation, and direct antibody injury [4]. It has excellent visual prognosis if treated promptly. A fundoscopic examination should be done early in patients with headache and other risk factors like severe renal involvement, APLA, hypertension, anemia, and serologically active disease to avoid permanent visual impairment from this potentially reversible condition $[4,5]$.

Arghya Chattopadhyay

dr.a.chattopadhyay@gmail.com

1 Department of Clinical Immunology and Rheumatology, Institute of Postgraduate Medical Education and Research, 244, A.J.C. Bose Road, Kolkata 700020, India

2 Department of Ophthalmology, Institute of Postgraduate Medical Education and Research, 244, A.J.C. Bose Road, Kolkata, West Bengal 700020, India 
Fig. 1 Fundus photography showed established papilledema with obscuration of neuroretinal rim and major blood vessels (a). Three weeks later, near recovery of papilledema was noted with blurring of only inferior and medial disc margins (b)

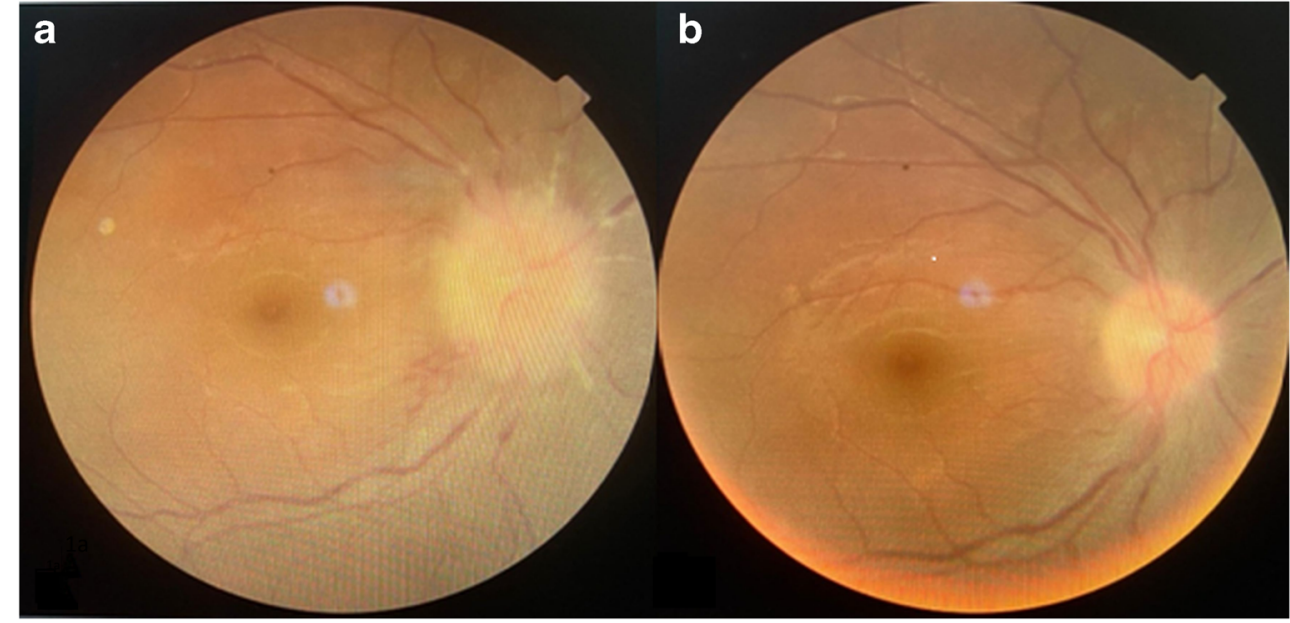

experience. Lupus 21(5):542-547. https://doi.org/10.1177/ 0961203311435267

3. Green L, Vinker S, Amital H, Amir T, Bar-Dayan Y, Levi Y, Schoenfeld Y (1995) Pseudotumor cerebri in systemic lupus erythematosus. Semin Arthritis Rheum 25:103-108. https://doi.org/10. 1016/s0049-0172(95)80023-9

4. Horoshovski D, Amital H, Katz M, Shoenfeld Y (1995) Pseudotumour cerebri in SLE. Clin Rheumatol 14:708-710. https://doi.org/10.1007/BF02207942

5. Nampoory MR, Johny KV, Gupta RK, Constandi JN, Nair MP, alMuzeiri I (1997) Treatable intracranial hypertension in patients with lupus nephritis. Lupus 6(7):597-602. https://doi.org/10.1177/ 096120339700600707

Publisher's note Springer Nature remains neutral with regard to jurisdictional claims in published maps and institutional affiliations. 